\title{
Assessing The Cost of Medical Care For Patients Hospitalized After A Stroke Event in Gabon
}

\section{Gaetan MOUKOUMBI LIPENGUET ( $\square$ moukoumbigaetan@gmail.com )}

Universite de Bordeaux

\section{Prudence GNAMIEN AMANI}

Universite de Bordeaux

\section{Euloge IBINGA}

Universite des Sciences de la Sante de Libreville

Jean Engohang-Ndong

Kent State University

\section{Edgard Brice NGOUNGO NGOUNGOU}

Universite des Sciences de la Sante de Libreville

Jérôme WITTWER

Universite de Bordeaux

\section{Research}

Keywords: Stroke, hospital care, direct hospital cost, Gabon

Posted Date: February 25th, 2021

DOI: https://doi.org/10.21203/rs.3.rs-230385/v1

License: @ (i) This work is licensed under a Creative Commons Attribution 4.0 International License. Read Full License 


\section{Abstract}

Background: The increasing incidence of recorded stroke cases is straining the economies of many developing countries. Very few studies have assessed the financial burden of stroke management in Gabon. The aim of this study was to assess the direct costs of stroke management in the neurology and cardiology departments at the University Hospital of Libreville.

Methods: This retrospective study was based on a detailed review of financial records directly associated with the management of stroke cases admitted and treated in the CHUL between January 2018 and December 2019. The records reviewed were those of all stroke patients admitted and treated in the aforementioned timeframe, regardless of treatment outcome. The analysis of data focused on direct hospital cost.

Results: Three hundred and thirteen stroke patients were admitted over the aforementioned period, $72.52 \%$ in neurology and $27.48 \%$ in cardiology. The average age of the patients was $58.44( \pm 13.73)$ years. $56.23 \%$ of patients had health insurance. Ischemic stroke was more common than hemorrhagic stroke, $79.55 \%$ and $20.45 \%$ respectively. The expenditure per patient was estimated at 570,023 CFA francs.

Of this global direct cost, government assistance in the form of health insurance was estimated at 422,883 CFA francs while the balance of approximately 147,140 CFA francs was paid by the patient.

Conclusion: The hospital cost of stroke is very high for both patients and administrations. This observation pleads for the implementation of prevention programs for this pathology. The results of this study may be useful for work on the efficiency of these programs.

\section{Introduction}

A stroke or cerebrovascular accident (CVA) is defined by the World Health Organization (WHO) as "rapidly developing clinical signs of focal (or global) disturbance of cerebral function, with symptoms lasting 24 hours or longer or leading to death, with no apparent cause other than of vascular origin" [1]. Typically, it results from the interruption of blood flow in the brain, usually when a blood vessel bursts or is blocked by a blood clot. Oxygen and nutrient supply are stopped which leads often time to irreversible brain tissue damages. This pathology is prevalent worldwide and affects both developed and developing countries. Although the prevalence of this disease is unknown in several developing countries, nevertheless, the number of cases is still high. According to the World Health Organization (WHO) data, in $2010,68.6 \%$ of new stroke cases, $70.9 \%$ deaths due to stroke, and $77.7 \%$ of years of life wasted due to residual disability or stroke-related death occurred in low- or middle-income countries [2].

Access to modern management methods such as intravascular thrombolysis, is trivialized in developed countries, however, access to these modern methods remains difficult in developing countries. The burden of this issue is not only felt socially, but also economically. In terms of health, the management of this pathology requires important human, material and financial resources to improve the life-threatening and functional prognosis of the patient. Numerous studies around the world show that this pathology is very expensive and represents a heavy burden on the health system, the economy of countries and for the patient who in some measures bears the cost of its care $[3,4,5]$. 
There is a very limited knowledge on the financial burden of stroke in developing countries. In the case of Gabon in particular, there is no known report published, neither by the government, nor by a team of researchers that assesses the costs of managing this pathology. The aim of this study is to assess the direct costs induced by the management of stroke cases in the Neurology and Cardiology Departments of the University Hospital Center of Libreville (CHUL, Centre Hospitalier Universitaire de Libreville). The outcome of this study could be useful in the future to perform efficiency studies of stroke prevention programs.

\section{Materials And Methods}

The study took place in the Cardiology and Neurology Departments of the University Hospital Center of Libreville in Gabon. Gabon has three (3) specialized University Hospital Centers (CHUs). Two CHUs located in two separate suburban areas of Libreville, one specializes in the care of the mother and child while the other focuses on treatment of trauma injuries. Unlike the two first CHUs, CHUL specializes in general medicine and specialties that are not managed at the other two suburban CHUs. Hence, CHUL is set to admit and treat most, if not all stroke cases recorded by the health system in Libreville and surrounding suburban areas.

We performed a retrospective study and careful analysis of archived stroke patient records over a two-year period spanning from January 2018 to December 2019. Only complete folders were included in this study. More specifically, a set of records was considered complete when a stroke patient folder contained all information necessary to confirm a stroke case including magnetic resonance imaging data and/or transient ischemic attack test along with all cost associated with patient care and patient treatment. Data used in this study for analysis were extracted from hospital records of stroke patients and made available to us by the Neurology and the Cardiology Departments of the CHUL. More specifically, we extracted on one hand, the nomenclatures of medical procedures and medications used to treat stroke patients, and, on another hand, the costs associated with those medical procedures and medications. Through that approach, we were able to determine the overall cost per stroke patient admitted.

More specifically, the method used involved two steps. In step one, clinical dada of patients were gathered along with medical procedures performed and the duration of hospital stay for each patient admitted. The second step consisted of gathering the cost for each medical procedure and the daily fees for the hospital room occupied by the stroke patient.

Costs per pharmaceutical product (medications and medical devices) were informed by the directory of medications reimbursed by the government medical insurance - CNAMGS (Caisse Nationale d'Assurance Maladie et de Garantie Sociale) 2013 and 2018 edition [6, 7]. In addition, we obtained from local pharmacies, supplemental information about the costs of medical items which payment was not covered by the government medical insurance.

The cost per medical procedure and costs of medications covered by medically insured patients (moderator ticket) were determined by taking into account co-payment preset by the medical insurance[1]. These copayments made by patients are set at $5 \%$ of the cost procedure and/or medications for patients affected and under a longterm condition plan (Carte ALD, Carte Affection de Longue Durée) while for heavy medical procedures or onerous medications, these copayments are set at $50 \%$ of the cost. For medical procedures requiring $50 \%$ of copayment, a document signed by the government medical insurance has to be provided by the patient to receive such benefit. 
These medical procedures include imaging procedures such as magnetic resonance imaging (MRI) and computed tomography (CT) scan. We were not able to secure long-term condition patients in our sample.

While costs of facility maintenance and electricity consumption were included in the flat rate hospitalization fees, salaries and wages of personnel per service were not included in medical expenses. Salaries and wages are paid by the government as most employees are civil servants of the country.

Data collected and recorded in a database were analyzed using the R version 3.6.1 software. Quantitative variables were expressed as mean values along with their standard deviations and qualitative data were expressed as percentage values.

\section{Results}

The collection of data was carried out in the Neurology and Cardiology Departments of the CHUL by thoroughly reviewing patient records. Altogether, 313 patient records were deemed complete which represented $92 \%$ of all stroke cases seen at the CHUL from 2018 to 2019. Among the 313 stroke patients were admitted and treated, 227 (72.52\%) were admitted in the Neurology Department and $86(27.48 \%)$ case admissions were recorded in the Cardiology Department. The average age of stroke patients was 58.44 ( \pm 13.73$)$ years. The average age for men was $57.81( \pm 12.80)$ years while that of women was $59.23( \pm 14.81)$ years. Out of 313 cases admitted, $56.23 \%$ of them had a government paid health insurance, compared to $43.77 \%$ who did not have health insurance. Ischemic strokes were more common than hemorrhagic strokes, $79.55 \%$ and $20.45 \%$, respectively. Table 1 summarizes the characteristics of our study population.

The cost variables were expressed in CFA Francs. The convertibility to euros is 655.975 euros for 1 CFA franc.

The overall cost of stroke management for the study period was estimated at 175,011,562 CFA francs

(266,785.92 euros) which represents an average cost per patient of 559,142 CFA francs (852.35 euros). Uninsured patients had a total expenditure of 74,687,400 CFA francs $(113,852.74$ euros). The average cost per uninsured patient was 545,163 CFA francs. The overall cost for insured patients was 100,324,162 CFA francs $(152,933.17$ euros). The proportion reimbursed to the hospital by the government medical insurance was 74,427,501 CFA francs $(113,456.55$ euros) and the remainder balance due by patients was 25,896,661 CFA francs $(39,476.62$ euros), with an average of 147,140 FCA francs (224.30 euros) per patient.

The overall cost of physiotherapy care was $17,280,000$ CFA francs (26,341.46 euros) with an average of 58,467 CFA francs (89.13 euros) per patient.

In terms of socio-demographic characteristics, our study found that patients under the age of 45 had a management cost that was higher than that of all other age groups with cost averaging 595,281 CFA francs $( \pm 263,512$ CFA francs). The next highest medical cost was incurred by patients for whom ages ranged from 55 to 65 with an average expense of 573,467 CFA francs ( $\pm 255,913$ CFA francs). We did not observe any difference in the average cost between women and men, regardless of the type of stroke. The cost according to the Glasgow coma score evolved with the score at the time of admission in the hospital. The highest cost was observed in patients for whom the score was comprised between 13 and 15. That cost per patient was 563,956 CFA francs (859.69 euros) (see table 2). 
The highest expenditure in case management was generated by hospitalization costs, followed by imaging examinations. Overall, the cost of hospitalization was $65,880,000$ CFA francs $(100,426.83$ euros), with an average per patient of 204,963 CFA francs (312.44 euros). The total cost of imaging examinations was 59,596,000 CFA francs (90,847.56 euros), with an average expense per patient that was 182,474 CFA francs (278.16 euros) (see table 3).

For insured patients, the highest expense was generated by imaging procedures, followed by hospitalization stay. Thus, records showed that imaging procedures came to a grand total cost of $10,429,400$ CFA francs $(15,898.47$ euros). Of that cost, on average, each patient was responsible for a copayment of 59,257FCFA (90.33 euros) while the insurance covered the remainder of the cost which was an average per patient of 137,315 CFA francs (209.32 euros). The total cost of hospitalization was 7,560,000 CFA francs (11,524.39 euros). Of that cost, patients were in charge of an average copayment per patient of 42,954 CFA francs (65.48 euros). The insurance was responsible of the remainder balance which was an average of 171,818 CFA francs (261.91 euros) per stroke patient admitted.

A multivariate linear regression was made for patients who were admitted in the Neurology Department as this department hosted the main stroke management service. That analysis allowed us to look for variation in cost and variation in length of hospital stay in the ward. Results of these regressions showed no association between sociodemographic factors, medical history and variation in length of hospitalization or in costs incurred by the neurology department. Management of cases appear to be homogeneous for all patients.

Table 3 presents all average costs including average costs incurred by uninsured patients, that of copayments due by insured patients, and that of shares paid by the government medical insurance for medical procedures and all expenses directly related to the treatment of patients.

The main expenditure items in patient-prescribed examinations were CT scans, which account for $41 \%$ of the expenditure related to imaging examinations, followed by cardiac ultrasounds with $20 \%$ of prescriptions. The average cost of the CT scan was 85,060 CFA francs (129.66 euros) higher than the MRI (magnetic resonance imaging) which cost was 16,102 CFA francs (24.54 euros).

The main expenditure items for laboratory tests were blood electrolyte and HIV serology, accounting for $20.38 \%$ and $20.02 \%$ respectively of the total expenditure related to laboratory tests (Table 4).

\section{Discussion}

The study we performed here allowed us to assess the direct cost associated with stroke management in the Neurology and Cardiology Departments of the Libreville University Hospital Center in Gabon. It provides new insights as of the direct costs of patient care from the government insurance perspective and for the years 2018 and 2019. Data collection was done by reviewing patient records in the aforementioned two departments. Thus, 313 complete patient records were screened in our study for the indicated period.

Our study indicated that the total cost of stroke management was 175,011,562 CFA francs (266.78 euros) with an average expense per patient that was found to be 559,142 CFA francs (852.35 euros). Out of this grand total amount of $175,011,562$ CFA francs, the government medical insurance was responsible for paying 74,427,501 CFA francs $(113,456.56$ euros) to the hospital for qualified patients while the $25,896,661$ CFA francs $(39,476.62$ 
euros) remaining balance was to be paid as copayment by patients. Insured patients paid on average 147,140FCFA (224.30 euros) per patients while uninsured patients paid on average 545,163 CFA francs (831.04 euros). On average, expenses incurred by uninsured patients are 3.7 times higher than expenses paid by government insure patients

As per analysis of patient records, we found that the actual occupancy of the hospital room and usage of utilities including electricity, generated the highest expense for case managements during hospitalization of stroke patients. On average, that expense per patient was 210,479 CAF francs (320.85euros). Hospitalization costs were immediately followed by imaging examinations with an average cost per patient of 207,169 CFA francs (315.81 euros). The two billing items represented $37.6 \%$ and $37.10 \%$ of the total stroke management burden for our study period, respectively.

The high cost of hospitalizations could be explained by the length of patient stay in wards which was 10.52 days on average per patient. In the CHUL context, hospital costs took into account room and board. Thus, a long hospital stay was an important determinant of cost increase in stroke management. This result is consistent with those reported by several other independent authors and described in the literature $[8,9,10]$.

In imaging examinations, CT scan ranks first with $41.06 \%$ of expenses. This could be explained by the systematic recommendation a CT scan as a routine procedure included in the diagnosis of strokes. As early as 1990, The Royal College of Physicians of London recommended a cerebral tomographic examination for all patients with sudden focal neurological deficit [11].

In laboratory testing, the blood electrolyte test represents $20.38 \%$ and HIV serology, $20.02 \%$ of the total expenses associated with to the costs of laboratory tests.

While insured patients paid out of pocket on average 147,140 CFA francs (224.30 euros), the government medical insurance paid to the hospital an average of 422,883FCFA (644.64 euros) per patient for the management of each insured stroke patient. On average per insured patient, imaging examinations costed 63,157 CFA francs (96.27 euros), followed by hospitalization fees with an average expenditure of 42,954 CFA francs (65.48 euros). The balance per patient due by the insurance for these two items were 152,915 CFA francs (233.10) and 171,818 CFA francs (261.92), respectively. The average hospitalization fees incurred by the insurance was higher than that of imaging examinations. This could be justified by the fact that some medical procedures such as MRIs, Angio MRIs and CT scans are only covered by insurance at 50\% while hospitalizations are supported by the insurance at $80 \%$ of the total cost.

Comparing the costs of stroke management performed by other groups in other countries seems a challenging task because disparities are tremendous between countries as realities of these health systems are so different across countries. Many countries, especially those in Subsaharan Africa face multiple problems in their health system including the lack of technical and modern infrastructures and also the limited human resource specialized in the management of this pathology. Nevertheless, our study is consistent with other studies in that stroke management is shown to be very expensive for both patients who sometimes support the cost of their care alone, and for states through government funded health insurance. Studies on the direct costs of care for stroke patients give us an idea of the burden of this medical condition in both developing and developed countries. 
The costs of stroke management, although clumped in one single treatment center, are comparable to those recorded in some African countries and those in Europe. A study conducted in Cameroon on 208 patients hospitalized for stroke with the diagnosis confirmed by CT scan, revealed an average cost per patient of 621,795 CFA francs (947.86) [12]. A one-year study for a sample of 78 patients in Benin showed an average cost per patient of 316,810 CFA francs (482.94 euros). This cost, while slightly below the cost we found in our study could be explained by the sample size and duration of the study. Indeed, our study included 4 times more patients than the study in Benin and covered a period of two years while the study in Benin cover only one year. Furthermore, in the same study performed in Benin, the highest expenditure item was attributed to paraclinical explorations (34.3\% of the total expenditure) and ranked costs of hospitalizations in third place [13]. In our study however, hospitalizations show the generate the highest costs compared to all other aspects. The average length of hospital stay is clearly a factor associated with the increased cost of stroke management.

In Senegal, the study of Touré et al. revealed an overall cost of stroke management of 32,614,442 CFA francs $(49,717.14$ euros), for 383 patients hospitalized for stroke. The average cost per patient was shown to be 78,426 CFA francs (119.55 euros) [14]. This cost included salary and wages, which may explain the difference observed in our study that did not take into account that aspect. In our study, this burden was carried by government which is in charge of salary and wages across the country and it cannot be dissociated. The highest expenditure item in the Touré et al. study was hospitalizations, which accounted for $57.8 \%$ of total expenditure. This is in line with our study where we show that hospitalizations occupied $37.6 \%$ of the total expenses, making it the highest expense of all.

The cost of stroke is very high around the world. In many cases, in spite of the fact that medical insurance covers part of the cost, the remainder balance is sometimes much higher than the purchasing power of patients, making this condition extremely burdensome for many populations. In Gabon, that situation is even worst given the low purchasing power of average citizens and the extremely low salaries and wages Gabonese workers receive. For insured patients, the average copayment was 147,140 CFA francs (224.30 euros) while the minimum wage in the country is set at 150,000 CFA francs (228.65 euros). As consequence, there is almost no different between the economic burden incurred by insured patients and the minimum wage in Gabon. For the uninsured patient, the cost of stroke management is 3 times higher than the minimum wage. That observation echoes the assertion of Callixte Kuate-Tegueu et al., who found that the cost of stroke management in Cameroon is 17 times higher than the minimum wage in that country [12], making stroke management unbearable for uninsured families of stroke patients. In Benin, Thierry Adoukonou et al., reported in their study that the cost of stroke management was 1.03 times the gross domestic product (GDP) per inhabitant [13].

\section{Conclusion}

Stroke is a burden on populations and economies of countries. Our study performed from a collective perspective point of view showed that the costs of managing this disease are very high for both patients and the community through government provided medical insurance. This study assessed only direct hospital and health care costs, but it did not include post-hospital nor indirect costs related to the loss of income for both the patient himself and/or the accompanying family member. Furthermore, this study did not include additional costs associated with the transportation of patients for medical procedures that were scheduled to take place at other health facilities. Nevertheless, the average expenditure per patient remained well above the Gabonese minimum wage. 


\section{Declarations}

Funding : Not applicable

Conflicts of interest/Competing interests : Not applicable

Availability of data and material : Data is available

Code availability : Not applicable

Ethics approval : Not applicable

Consent to participate: The authors have freely consented to the writing of this article

Consent for publication : The authors have freely consented to the publication of this article

\section{References}

1. WHO. World Health Report, Geneva; (2000).

2. Organisation Mondiale de la Santé. Rapport d'activité; (2010).

3. Touré K, Ndiaye NM, Sène Diouf F, Ndiaye M, Diallo AM, Ndao AK, et al Evaluation du coût de prise en charge des accidents vasculaires cérébraux à Dakar - Sénégal, Médecine Tropicale; (2005). 65;5.

4. De Pouvourville G. Coût de la prise en charge des accidents vasculaires cérébraux en France. Archives of Cardiovascular Diseases Supplements. 2016;8:161-8.

5. Adoukonou T, Kouna-Ndouongo P, Codjia JM, Covi R, Tognon-Tchegnonsi F, Preux PM, et al Coût direct des accidents vasculaires cérébraux au CHU de Parakou. Revue Neurologique, Volume 173, Supplement 2, March (2017), Page S190.

6. Caisse Nationale d'Assurance Maladie et de Garantie Sociale. Liste des médicaments remboursables par CNAMGS, Edition. (2013) (Gabon).

7. Caisse Nationale d'Assurance Maladie et de Garantie Sociale. Liste des médicaments remboursables par CNAMGS, Edition. (2018) (Gabon).

8. Gioldasis G, Talelli P, Chroni E, Daouli J, Papapetropoulos T, Ellul J. In-hospital direct cost of acute ischemic and hemorrhagic stroke in Greece. Acta Neurol Scand. (2008); 118(4): 268 - 74. PubMed I Google Scholar.

9. Saxena SK, Ng TP, Yong D, Fong NP, Gerald K. Total direct cost, length of hospital stay, institutional discharges and their determinants from rehabilitation settings in stroke patients. Acta Neurol Scand. 2006;114(5):307-14. PubMed | Google Scholar.

10. Rossnagel K, Nolte CH, Muller-Nordhorn J, Jungehulsing GJ, Selim D, Bruggenjurgen B, et al. Medical resource use and costs of health care after acute stroke in Germany. Eur J Neurol. 2005;12(11):862-8. PubMed | Google Scholar.

11. Royal college of physicians of London. - Stroke: towards better management. Summary and recommendations. J Roy College Physicians London. 1990;24:15-7.

12. Kenmogne Kountchou MA, Kuate Tegueu C, Doumbe JN, Mapoure Y, Tchaleu B, Noubissi G, et al Variations et déterminants du coût de prise en charge hospitalière des accidents vasculaires cérébraux au Cameroun. Revue Neurologique, Volume 173, Supplement 2, March (2017), Pages S97-S98. 
13. Adoukonou T, Kouna-Ndouongo P, Codjia JM, Covi R, Tognon-Tchegnonsi F, Preux PM, et al. Cout direct hospitalier des accidents vasculaires cérébraux à Parakou au nord du Benin. Pan African Medical Journal. 2013;16:121. doi:10.11604/pamj.2013.16.121.2790.

14. Touré $K$, Ndiaye NM, Sène Diouf F, Ndiaye M, Diallo AM, Ndao AK, et al. Evaluation du coût de prise en charge des accidents vasculaires cérébraux à Dakar - Sénégal. Med Trop. 2005;65:458-64.

\section{Tables}

Table 1: Characteristics of the study population 


\begin{tabular}{|c|c|c|c|}
\hline & $\begin{array}{l}\text { Total } \\
\text { Patients }\end{array}$ & $\begin{array}{l}\text { Insured Patients } N=176 \\
(56.23 \%)\end{array}$ & $\begin{array}{l}\text { Uninsured Patients } \mathrm{N}=137 \\
(43.76 \%)\end{array}$ \\
\hline & \multicolumn{3}{|l|}{$N=313$} \\
\hline \multicolumn{4}{|l|}{ Variable } \\
\hline Age, average (SD) & $\begin{array}{l}58.43 \\
(13.75)\end{array}$ & $58.79(14.83)$ & $57.96(12.26)$ \\
\hline \multicolumn{4}{|l|}{ Sex, N (\%) } \\
\hline Male & $173(55.27)$ & $83(47.16)$ & $90(65.69)$ \\
\hline Female & $140(44.73)$ & $93(52.84)$ & $47(34.31)$ \\
\hline \multicolumn{4}{|l|}{ Medical history, N (\%) } \\
\hline Arterial hypertension & $244(77.96)$ & $141(80.11)$ & $103(75.18)$ \\
\hline Diabetes & $262(83.71)$ & 145 (82.39) & $117(85.4)$ \\
\hline Hypercholesterolemia & $301(96.71)$ & 170 (96.59) & 131 (95.62) \\
\hline Alcohol & $163(52.08)$ & $94(53.41)$ & $69(50.36)$ \\
\hline \multicolumn{4}{|l|}{$\begin{array}{l}\text { Healthcare service, } \mathrm{N} \\
(\%)\end{array}$} \\
\hline Neurology & $227(72.52)$ & $120(68.18)$ & $107(781)$ \\
\hline Cardiology & $86(27.48)$ & $56(31.82)$ & 30 (219) \\
\hline \multicolumn{4}{|l|}{ Type of Stroke N (\%) } \\
\hline Ischemic & $249(79.55)$ & $140(79.55)$ & 109 (79.56) \\
\hline Haemorrhagic & $64(20.45)$ & $36(20.45)$ & $28(20.44)$ \\
\hline \multicolumn{4}{|l|}{ Outcome, N (\%) } \\
\hline Patient Discharged & $265(84.66)$ & $153(86.93)$ & $112(81.75)$ \\
\hline Transferred & $22(7.03)$ & $11(6.25)$ & $11(8.03)$ \\
\hline Deceased & $23(7.35)$ & $12(6.82)$ & $11(8.03)$ \\
\hline Escaped & $3(0.96)$ & $0(0)$ & $3(2.19)$ \\
\hline \multicolumn{4}{|l|}{ Marital status, N (\%) } \\
\hline Single & $97(30.99)$ & $56(31.82)$ & $41(29.93)$ \\
\hline Domestic Partnership & $40(12.78)$ & $24(13.64)$ & $16(11.68)$ \\
\hline Married & $128(40.89)$ & $67(38.07)$ & $61(44.53)$ \\
\hline Divorced & $3(0.96)$ & $2(1.14)$ & $1(0.73)$ \\
\hline Widowed & $45(14.38)$ & $27(15.34)$ & $18(13.14)$ \\
\hline
\end{tabular}




\begin{tabular}{|llll|}
\hline Non specified & $92(29.39)$ & $58(32.95)$ & $34(24.82)$ \\
\hline Unemdent & $1(0.32)$ & $1(0.57)$ & - \\
\hline $\begin{array}{l}\text { Medium class } \\
\text { employee }\end{array}$ & $19(6.07)$ & $14(7.95)$ & $5(3.65)$ \\
\hline Senior Officer & $15(15.34)$ & $31(17.61)$ & $17(12.63)$ \\
\hline Manual Laborer & $50(15.97)$ & $12(6.82)$ & $5(3.65)$ \\
\hline Civil Servant & $9(2.88)$ & $6(3.41)$ & $38(27.74)$ \\
\hline Trader & $6(1.92$ & $2(1.14)$ & $3(2.19$ \\
\hline Retired & $73(23.32)$ & $42(23.86)$ & $4(2.92)$ \\
\hline
\end{tabular}

Table 2: Average costs* by socio-demographic characteristics 


\begin{tabular}{|c|c|c|c|c|c|}
\hline \multirow[t]{2}{*}{ Characteristics } & \multirow{2}{*}{$\begin{array}{l}\text { Uninsured } \\
\text { patients }\end{array}$} & \multicolumn{3}{|c|}{ Insured patients } & \multirow{2}{*}{$\begin{array}{l}\text { Global } \\
\text { average }\end{array}$} \\
\hline & & Total & $\begin{array}{l}\text { Insurance } \\
\text { coverage }\end{array}$ & $\begin{array}{l}\text { Patient } \\
\text { copayment }\end{array}$ & \\
\hline \multicolumn{6}{|l|}{ Age, average (SD) } \\
\hline$\leq 45$ & $\begin{array}{l}565997 \\
(222617)\end{array}$ & $\begin{array}{l}613916 \\
(288292)\end{array}$ & $\begin{array}{l}455984 \\
(208967)\end{array}$ & $\begin{array}{l}157932 \\
(85767)\end{array}$ & $\begin{array}{l}595281 \\
(263512)\end{array}$ \\
\hline$[45-55[$ & $\begin{array}{l}520556 \\
(154608)\end{array}$ & $\begin{array}{l}553399 \\
(197361)\end{array}$ & $\begin{array}{l}412629 \\
(140561)\end{array}$ & $\begin{array}{l}140770 \\
(61713)\end{array}$ & $\begin{array}{l}535646 \\
(175072)\end{array}$ \\
\hline [55-65[ & $\begin{array}{l}581206 \\
(320175)\end{array}$ & $\begin{array}{l}567216 \\
(192158)\end{array}$ & $\begin{array}{l}416434 \\
(118346)\end{array}$ & $\begin{array}{l}150782 \\
(81174)\end{array}$ & $\begin{array}{l}573467 \\
(255913)\end{array}$ \\
\hline$\geq 65$ & $\begin{array}{l}516721 \\
(205764)\end{array}$ & $\begin{array}{l}557088 \\
(235478)\end{array}$ & $\begin{array}{l}415719 \\
(174517)\end{array}$ & $\begin{array}{l}141368 \\
(68380)\end{array}$ & $\begin{array}{l}542006 \\
(224526)\end{array}$ \\
\hline \multicolumn{6}{|l|}{ Sex, average (SD) } \\
\hline Male & $\begin{array}{l}553723 \\
(257524)\end{array}$ & $\begin{array}{l}574058 \\
(248731)\end{array}$ & $\begin{array}{l}425692 \\
(177171)\end{array}$ & $\begin{array}{l}148366 \\
(79300)\end{array}$ & $\begin{array}{l}563479 \\
(252813)\end{array}$ \\
\hline Female & $\begin{array}{l}528772 \\
(193222)\end{array}$ & $\begin{array}{l}566422 \\
(206961)\end{array}$ & $\begin{array}{l}420376 \\
(145170)\end{array}$ & $\begin{array}{l}146045 \\
(70006)\end{array}$ & $\begin{array}{l}528772 \\
(193222)\end{array}$ \\
\hline \multicolumn{6}{|c|}{ Type stroke, average (SD) } \\
\hline Ischemic & $\begin{array}{l}543345 \\
(241084)\end{array}$ & $\begin{array}{l}568506 \\
(227181)\end{array}$ & $\begin{array}{l}422465 \\
(163157)\end{array}$ & $\begin{array}{l}146040 \\
(73081)\end{array}$ & $\begin{array}{l}557491 \\
(233227)\end{array}$ \\
\hline Haemorrhagic & $\begin{array}{l}552242 \\
(224439)\end{array}$ & $\begin{array}{l}575925 \\
(229331)\end{array}$ & $\begin{array}{l}424509 \\
(152474)\end{array}$ & $\begin{array}{l}151416 \\
(79926)\end{array}$ & $\begin{array}{l}565564 \\
(225714)\end{array}$ \\
\hline \multicolumn{6}{|c|}{ Glasgow Score, Average (SD) } \\
\hline$\leq 6$ & - & - & - & - & - \\
\hline$[6-8[$ & - & $386763(-)$ & $294081(-)$ & $92682(-)$ & $386763(-)$ \\
\hline [8-13[ & $\begin{array}{l}443241 \\
(196658)\end{array}$ & $\begin{array}{l}579937 \\
(171025)\end{array}$ & $\begin{array}{l}430891 \\
(119929)\end{array}$ & $\begin{array}{l}149045 \\
(58224)\end{array}$ & $\begin{array}{l}516471 \\
(192944)\end{array}$ \\
\hline [13-15] & $\begin{array}{l}555848 \\
(238972)\end{array}$ & $\begin{array}{l}570239 \\
(232186)\end{array}$ & $\begin{array}{l}422937 \\
(164357)\end{array}$ & $\begin{array}{l}147301 \\
(75914)\end{array}$ & $\begin{array}{l}563956 \\
(234863)\end{array}$ \\
\hline \multicolumn{6}{|c|}{ Medical History, Average (SD) } \\
\hline HTA & $545223(239727)$ & $\begin{array}{l}576595 \\
(220457)\end{array}$ & $\begin{array}{l}428240 \\
(156077)\end{array}$ & $\begin{array}{l}148355 \\
(72331)\end{array}$ & $\begin{array}{l}563352 \\
(228833)\end{array}$ \\
\hline Diabetes & $564701(400068)$ & $\begin{array}{l}605682 \\
(263266)\end{array}$ & $\begin{array}{l}453894 \\
(196079)\end{array}$ & $\begin{array}{l}151788 \\
(70626)\end{array}$ & $\begin{array}{l}589611 \\
(320647)\end{array}$ \\
\hline Hypercholesterolemia & $517642(160492)$ & $\begin{array}{l}436161 \\
(208264)\end{array}$ & $\begin{array}{l}329271 \\
(154014)\end{array}$ & $\begin{array}{l}106890 \\
(54665)\end{array}$ & $\begin{array}{l}476902 \\
(182302)\end{array}$ \\
\hline Alcohol & $541271(194445)$ & $\begin{array}{l}558090 \\
(232788)\end{array}$ & $\begin{array}{l}414151 \\
(162167)\end{array}$ & $\begin{array}{l}143939 \\
(78256)\end{array}$ & $\begin{array}{l}550971 \\
(216908)\end{array}$ \\
\hline
\end{tabular}


*Costs were expressed in CFA francs

Table 3 : Average costs* per station and per patient (insured and uninsured).

\begin{tabular}{|c|c|c|c|c|c|c|c|}
\hline \multirow{2}{*}{$\begin{array}{l}\text { Nature of the } \\
\text { care }\end{array}$} & \multirow{2}{*}{$\begin{array}{l}\text { Global N(\% } \\
\text { expense) }\end{array}$} & \multirow{2}{*}{$\begin{array}{l}\text { Average } \\
\text { for } \\
\text { uninsured } \\
\text { patients } \\
(\mathrm{N}=137)\end{array}$} & \multicolumn{3}{|c|}{ Insured patients } & \multicolumn{2}{|c|}{ All Patients } \\
\hline & & & $\begin{array}{l}\text { Insured } \\
\text { patients }\end{array}$ & $\begin{array}{l}\text { Patient } \\
\text { copayment } \\
(\mathrm{N}=176)\end{array}$ & $\begin{array}{l}\text { Insurance } \\
\text { contribution } \\
(\mathrm{N}=176)\end{array}$ & $\begin{array}{l}\text { Average } \\
(\mathrm{N}=313)\end{array}$ & Extreme \\
\hline Consultation & $\begin{array}{l}3130000 \\
(1.8)\end{array}$ & 10000 & 10000 & 2000 & 8000 & 10000 & $\begin{array}{l}\text { [10000 - } \\
10000]\end{array}$ \\
\hline Hospitalization & $\begin{array}{l}65880000 \\
(37.6)\end{array}$ & 204963 & 214772 & 42954 & 171818 & 210479 & $\begin{array}{l}\text { [20000 - } \\
1900000]\end{array}$ \\
\hline $\begin{array}{l}\text { Laboratory } \\
\text { tests }\end{array}$ & $\begin{array}{l}13862000 \\
(7.9)\end{array}$ & 45583 & 43278 & 8911 & 34367 & 44287 & $\begin{array}{l}{[0-} \\
685000]\end{array}$ \\
\hline $\begin{array}{l}\text { Imaging } \\
\text { exams }\end{array}$ & $\begin{array}{l}64844000 \\
(37.1)\end{array}$ & 195729 & 216073 & 63157 & 152915 & 207169 & $\begin{array}{l}{[20000-} \\
709000]\end{array}$ \\
\hline Physiotherapy & $\begin{array}{l}17280000 \\
(9.9)\end{array}$ & 58467 & 52670 & 16971 & 35698 & 55207 & $\begin{array}{l}{[0-} \\
90000]\end{array}$ \\
\hline Medicines & $\begin{array}{l}10015562 \\
(5.7)\end{array}$ & 30418 & 33228 & 13144 & 20283 & 31998 & $\begin{array}{l}{[0-} \\
146540]\end{array}$ \\
\hline Total & $\begin{array}{l}175011562 \\
(100)\end{array}$ & 545163 & 570023 & 147140 & 422883 & 559142 & $\begin{array}{l}\text { [151068- } \\
2158390]\end{array}$ \\
\hline
\end{tabular}

*Costs were expressed in CFA francs

Table 4: Unit costs and costs by type of exam 


\begin{tabular}{|llllll|}
\hline Type of exam & $\begin{array}{c}\text { Number of } \\
\text { achievements (\%) }\end{array}$ & $\begin{array}{l}\text { Unit } \\
\text { cost }\end{array}$ & $\begin{array}{l}\text { All } \\
\text { Patient }\end{array}$ & $\begin{array}{l}\text { Insured } \\
\text { patients }\end{array}$ & $\begin{array}{l}\text { Uninsured } \\
\text { patients }\end{array}$ \\
\hline Imaging exam (\% of imaging exam expenditure) & & & & \\
\hline MRI (7.77\%) & $19(6.07)$ & 260000 & 16102 & 16250 & 15912 \\
\hline CT scan (41.06\%) & $256(81.79)$ & 104000 & 85060 & 86272 & 83503 \\
\hline EKG (7.22\%) & $234(61.34)$ & 20000 & 14952 & 15681 & 14014 \\
\hline Cardiac ultrasound (20.45\%) & $204(65.18)$ & 20000 & 42364 & 43210 & 41277 \\
\hline $\begin{array}{l}\text { Ultrasound of neck vessels } \\
\text { (14.68\%) }\end{array}$ & $136(43.45)$ & 70000 & 29635 & 31022 & 29635 \\
\hline $\begin{array}{l}\text { Angio-MRI Angioscanner } \\
\text { (8.82\%) }\end{array}$ & $22(7.03)$ & 260000 & 18274 & 23636 & 11386 \\
\hline Laboratory tests (\% of laboratory test expenditure) & & & & \\
\hline Glycemia (5.30\%) & $245(78.27)$ & 3000 & 2348 & 2301 & 2408 \\
\hline NFS (13.96\%) & $258(82.43)$ & 7500 & 6182 & 5923 & 6514 \\
\hline LDL Cholesterol (4.48\%) & $207(66.13)$ & 3000 & 1984 & 2028 & 1927 \\
\hline HDL Cholesterol (4.39\%) & $203(66.13)$ & 3000 & 1945 & 1926 & 1970 \\
\hline Triglycerides (3.94\%) & $182(58.15)$ & 3000 & 1744 & 1653 & 1861 \\
\hline Electrolytes (20.38\%) & $226(72.2)$ & 12500 & 9025 & 8735 & 9397 \\
\hline Urea (5.76\%) & $274(87.54)$ & 3500 & 2549 & 2068 & 3167 \\
\hline Creatinine (7.07\%) & $280(89.46)$ & 3500 & 3130 & 3062 & 3218 \\
\hline Total Protein (4.57\%) & $181(57.83)$ & 3500 & 2023 & 2147 & 1864 \\
\hline Tck (3.59\%) & $171(54.63)$ & 3500 & 1587 & 1670 & 1481 \\
\hline HIV serologies (20.02\%) & $185(59.11)$ & 15000 & 8865 & 8778 & 8978 \\
\hline TPHA VDRL (6.55\%) & $192(61.34)$ & 7500 & 2899 & 2982 & 2791 \\
\hline
\end{tabular}

${ }^{*}$ Costs were expressed in CFA francs 